\title{
Emerging potential of gene silencing approaches targeting anti-chondrogenic factors for cell-based cartilage repair
}

\author{
Andrea Lolli ${ }^{1}$ - Letizia Penolazzi ${ }^{2}$ Roberto Narcisi ${ }^{1}$ - Gerjo J. V. M. van Osch ${ }^{1,3}$ - Roberta Piva ${ }^{2}$
}

Received: 16 February 2017/Revised: 14 April 2017 / Accepted: 19 April 2017

(C) Springer International Publishing 2017

\begin{abstract}
The field of cartilage repair has exponentially been growing over the past decade. Here, we discuss the possibility to achieve satisfactory regeneration of articular cartilage by means of human mesenchymal stem cells (hMSCs) depleted of anti-chondrogenic factors and implanted in the site of injury. Different types of molecules including transcription factors, transcriptional co-regulators, secreted proteins, and microRNAs have recently been identified as negative modulators of chondroprogenitor differentiation and chondrocyte function. We review the current knowledge about these molecules as potential targets for gene knockdown strategies using RNA interference (RNAi) tools that allow the specific suppression of gene function. The critical issues regarding the optimization of the gene silencing approach as well as the delivery strategies are discussed. We anticipate that further development of these techniques will lead to the generation of implantable hMSCs with enhanced potential to regenerate articular cartilage damaged by injury, disease, or aging.
\end{abstract}

Andrea Lolli

a.lolli@erasmusmc.nl

Roberta Piva

piv@unife.it

1 Department of Orthopaedics, Erasmus MC, University Medical Center, 3015 CN Rotterdam, The Netherlands

2 Department of Biomedical and Specialty Surgical Sciences, University of Ferrara, Ferrara, Italy

3 Department of Otorhinolaryngology, Erasmus MC, University Medical Center, 3015 CN Rotterdam, The Netherlands
Keywords Gene silencing · RNA interference · MicroRNA - Cartilage repair - Chondrogenesis . Mesenchymal stem cells $\cdot$ Anti-chondrogenic regulators

$\begin{array}{ll}\text { Abbreviations } \\ \text { AIMP1 } & \begin{array}{l}\text { Aminoacyl tRNA synthetase complex } \\ \text { interacting multifunctional protein 1 }\end{array} \\ \text { ANGPTL4 } & \text { Angiopoietin-like 4 } \\ \text { BMP } & \text { Bone morphogenetic protein } \\ \text { circRNA } & \text { Circular RNA } \\ \text { ECM } & \text { Extracellular matrix } \\ \text { EMT } & \text { Epithelial-to-mesenchymal transition } \\ \text { ERK } & \text { Extracellular signal-regulated kinase } \\ \text { EV } & \text { Extracellular vesicle } \\ \text { FGF } & \text { Fibroblasts growth factor } \\ \text { GAG } & \text { Glycosaminoglycan } \\ \text { hMSCs } & \text { Human mesenchymal stem cells } \\ \text { IGF } & \text { Insulin-like growth factor } \\ \text { IHH } & \text { Indian hedgehog } \\ \text { IKK } & \text { IkB kinase } \\ \text { JNK } & \text { C-Jun N-terminal kinase } \\ \text { KDM2A } & \text { Lysine demethylase 2A } \\ \text { lncRNA } & \text { Long non-coding RNA } \\ \text { MAPK } & \text { Mitogen-activated protein kinase } \\ \text { MCC } & \text { Mandibular condylar cartilage } \\ \text { MEK } & \text { Mitogen-activated protein kinase } \\ \text { MMP } & \text { Matrix metalloproteinase } \\ \text { NP } & \text { Nanoparticle } \\ \text { OA } & \text { Osteoarthritis } \\ \text { p53R2 } & \text { p53-Inducible ribonucleotide reductase } \\ \text { PAMAM } & \text { Polyamidoamine } \\ \text { PEI } & \text { Polyethylenimine } \\ \text { PHD2 } & \text { Prolyl hydroxylase } \\ & \text { protein 2 domain-containing } \\ & \end{array}$




$\begin{array}{ll}\text { PLGA } & \text { Poly(D,L-lactide-co-glycolide) } \\ \text { PLL } & \text { Poly-L-lysine } \\ \text { PNA } & \text { Peptide nucleic acid } \\ \text { QD } & \text { Quantum dot } \\ \text { RISC } & \text { RNA-induced silencing complex } \\ \text { RNAi } & \text { RNA interference } \\ \text { RUNX2 } & \text { Runt-related transcription factor 2 } \\ \text { shRNA } & \text { Short hairpin RNA } \\ \text { siRNA } & \text { Short interfering RNA } \\ \text { SOX } & \text { SRY (sex determining region Y)-box } \\ \text { TF } & \text { Transcription factor } \\ \text { TGF } & \text { Transforming growth factor } \\ \text { TGIF1 } & \text { TGF- } \beta \text { induced factor homeobox 1 } \\ \text { VEGF } & \text { Vascular endothelial growth factor }\end{array}$

\section{Introduction}

Currently, trauma and age-related cartilage disorders represent a major cause of morbidity globally and result in enormous costs for health and social care systems [1]. As a consequence, there is an urgent need for interventions that can help to prevent these disorders and therapies to effectively treat them. To date, these objectives are far from being achieved and optimal cartilage reconstruction still represents an unmet clinical need [2,3].

Cell-based therapy for cartilage repair aims at not only filling the tissue defect with a substitute, but also reconstituting the structure, physicochemical properties, and functionality of the hyaline matrix, possibly promoting intimate integration with the resident tissue $[4,5]$. Ideally, this is achieved by implanting a sufficient number of mature chondrocytes or undifferentiated progenitor cells with a high chondrogenic potential [6]. Recently, experimental therapies using mesenchymal stem cells (MSCs) have been receiving an increasing amount of interest, mostly due to the ease of isolation and their regenerative potential [7-9]. Unfortunately, the use of native unaltered chondrogenic cells, either chondrocytes or MSCs, has not fulfilled expectations, with the underlying mechanisms of tissue regeneration still poorly understood [10]. This has laid the basis for the experimental transplantation of genetically modified cells, as a revolutionary approach to exploit the full potential of the therapeutic cells. Chondrocytes and more recently MSCs have extensively been modified using a variety of techniques allowing the manipulation of critical genes that can directly or indirectly affect chondrogenesis and/or production of cartilage matrix [11]. This has been made possible by the recent advancements in cell engineering technologies, together with a progressive understanding of the molecular basis of chondrogenesis.
Chondrogenesis is the process by which cartilage is developed and occurs via mesenchymal cell condensation and chondroprogenitor cell differentiation (reviewed in $[12,13])$. Several molecular pathways, mechanical stimuli, and morphological cell features contribute to the activation of the signals that drive the chondrogenic process, as well as the transition through the different maturation stages. A critical role is played by (a) soluble factors, e.g., fibroblasts growth factors (FGFs), transforming growth factors (TGF$\beta s$ ), insulin-like growth factors (IGFs), bone morphogenetic proteins (BMPs) and WNTs, (b) cell adhesion molecules, e.g., $\mathrm{N}$-cadherin and integrins, and (c) intracellular signaling molecules, including mitogen-activated protein kinase (MAPKs), c-Jun N-terminal kinases (JNKs), protein kinase $\mathrm{A} / \mathrm{C}$, and protein phosphatase $2 \mathrm{~A} / 2 \mathrm{~B}$ [14].

While the transcriptional control of chondrogenesis remains to be fully elucidated, it is well established that SRY (sex determining region Y)-box 9 (SOX9) is the pivotal transcription factor in developing and adult cartilage [12]. SOX9, in concert with L-SOX5 and SOX6 (collectively referred to as the SOX-trio), regulates cartilage formation and maintains the chondrocyte phenotype in articular cartilage by stimulating the expression of specific genes, including collagen type II, IX, and XI, aggrecan, and cartilage oligomeric matrix protein (COMP) [12]. SOX9 supports chondrogenesis over osteogenesis by negatively regulating Runt-related transcription factor 2 (RUNX2), the major transcription factor required for osteoblast differentiation, and WNT signaling via nuclear $\beta$-catenin phosphorylation [15]. In growth plate cartilage, inhibition of SOX proteins leads to chondrocyte maturation and hypertrophy that is required for longitudinal bone growth. Hypertrophic chondrocytes are characterized by increased expression of parathyroid-related peptide, Indian hedgehog (IHH), vascular endothelial growth factor (VEGF), collagen type $\mathrm{X}$, and matrix metalloproteinase 13 (MMP13) [12]. Differences between the regulation and gene expression profiles of growth plate and articular chondrocytes reflect the different functions of the two types of cartilage. This relates to the necessity to maintain cell proliferation and maturation in the growth plate, while preventing chondrocyte hypertrophy in articular cartilage [16].

Traditionally, engineering techniques for the enhancement of chondrogenesis have primarily focused on the forced expression of growth factors, mainly IGFs, FGFs, TGF- $\beta$ s, and BMPs, or pro-chondrogenic transcription factors, e.g., SOX5, SOX6, and SOX9. Alternatively, chondroprotective factors, cytokines, and inhibitors of catabolic pathways have been proposed (a comprehensive list of these factors has been reported previously in [11]). While forcing the expression of a gene during ex vivo cell culture is relatively simple, the process cannot be tightly 
controlled, especially in case of permanent overexpression [17]. Excessive gene overexpression may cause imbalance in gene dosage, affecting protein synthesis, folding, and localization, assembly of multiprotein complexes, and the machinery of gene regulation. Flooding the cell with recombinant proteins may lead to excessive consumption of cellular resources, affecting cell growth rate and metabolism [18]. While these aspects are often overlooked, they represent serious concerns in view of a wider applicability and clinical translation of overexpression-based strategies.

More recently, alternative strategies to engineer chondrocytes or MSCs for enhanced cartilage repair have emerged. These approaches are based on the silencing of anti-chondrogenic factors and aim to suppress the function of proteins negatively affecting chondrogenesis, or whose expression is detrimental for the chondrogenic potential. The main purpose of this review is to report evidence and challenges regarding the silencing of anti-chondrogenic factors as an attractive option for cell-based cartilage repair, pointing out that the optimization of such an approach is needed.

\section{Gene silencing for chondrogenesis: potentialities and challenges}

Gene silencing strategies for chondrogenesis use RNA interference (RNAi) tools, e.g., short interfering RNAs (siRNAs), short hairpin RNAs (shRNAs), and microRNA inhibitors (antimiRs), that allow the specific suppression of the function of a gene. Importantly, a number of early proof-of-principle studies in animal models and early phase clinical trials have supported the use of RNAi as therapeutic agents in different fields, without significant toxicity (reviewed in [19]). In sharp contrast with overexpression strategies, RNAi research tools are inspired by the natural phenomena of suppression of gene expression operating in various forms of life for genome integrity, defense against viruses or exogenous nucleic acids, and transcriptional regulation [20]. Moreover, RNAi techniques require a limited utilization of cellular resources and do not overload the cell or the extracellular environment with transgene products [17]. Thus, it is likely that the cells are less stressed by RNAi rather than overexpression treatments.

Gene silencing represents a simple and powerful molecular tool to investigate the specific function of genes during chondrogenesis, providing critical insights into cartilage-specific regulatory mechanisms and chondroregulators. Interestingly, the accumulating knowledge has led to the development of new therapeutic strategies based on the silencing of negative chondro-regulators. The products of these genes can be classified as anti-chondrogenic or pro-hypertrophic, as they can take part in lowering the chondrogenic potential of the cells, or in undermining the functionality of the newly formed tissue.

Research based on gene silencing for the enhancement of chondrogenesis is still in its infancy and, besides a few exceptions, has not proceeded to extensive in vivo testing yet. Nevertheless, increasing evidence strongly suggests that the silencing of key anti-chondrogenic regulators may be effectively employed to enhance or even induce chondrogenesis, stimulate the production of cartilage matrix, and improve or stabilize the chondrocytic phenotype [21-24].

Without intending to be exhaustive, we provide a brief overview of critical issues related to the application of gene silencing for chondrogenesis, with a focus on MSCs, and the barriers that they pose for RNAi delivery. Here, different aspects must be taken into account, as the peculiar characteristics of MSCs make them harder to transfect than conventional cell lines [25]. Transfection or transduction efficiency in MSCs is highly species, source, and donordependent, and can be significantly affected by in vitro culture conditions, including composition of culture medium, cell density and proliferation rate, passage number, and cell distribution [26]. This is a general principle related to transfection, but gene manipulation for chondrogenesis poses an additional obstacle which is the need to grow the cells in a 3D system, a very unfavourable condition for transfection [27]. However, 3D culture is essential to recapitulate the chondrogenic process in vitro, and maintain the therapeutic potential of MSCs for subsequent in vivo implantation.

To overcome the aforementioned obstacles, MSCs can be transduced with viral vectors. This rapidly induces permanent silencing of specific molecules that affect the chondrogenic process. A variety of viral vectors are available to achieve this goal, each of which has advantages and limitations [28]. The recombinant adenoassociated vectors are nowadays regarded as the most potent gene delivery vehicles, as they can efficiently and durably transduce articular chondrocytes, synoviocytes, MSCs, and other relevant cell sources constituting the surrounding tissues of cartilage [11]. Unfortunately, virusbased methods for gene silencing pose many issues in regards to their clinical translation and applicability. Safety concerns have been raised in relation to their use for gene silencing in vivo, due to potential immune response of the host, possible mutagenesis, and lack of specificity in addition to high production costs. As a consequence, virusfree approaches of transient transfection are being widely explored.

It is now widely accepted that non-viral vectors are preferable for in vivo use, since they are safe, easy to handle, cost-effective, and they have better chances for clinical translation (recently reviewed in [29]). In addition, 
this choice may be convenient for engineered cells to prime the regeneration process by triggering repair mechanisms as well as to stimulate an active involvement of the host tissues in the repair of the defect [30]. Transient techniques for gene silencing are receiving an increasing amount of interest, since the progress in RNAi techniques has led to the development and optimization of cell transfection in 3D microenvironment, with exogenous scaffolds being able to greatly increase efficiency and durability of gene silencing [29]. Interestingly, RNAi transfection may be performed by growing cells within a 3D matrix in which the RNAi has previously been entrapped or cross-linked [31]. Alternatively, cells may be transfected with RNAi molecules prior seeding onto scaffolds or 3D-culture, under conditions that guarantee a prolonged suppression of the target gene [32].

\section{Non-viral methods delivering RNAi for chondrogenesis}

Since the ECM produced by the cells during chondrogenic differentiation represents a considerable obstacle for transfection, RNAi delivery is likely the major critical issue for successful gene silencing. Effective gene knockdown requires efficient uptake of the RNAi molecules by the cells, and their retention in the cytoplasmic compartment where the RNAi machinery is located. Only here, the inhibitor can enter the endogenous RNAi pathway, integrating into the RNA-induced silencing complex (RISC) and leading to silencing of the target $[20,33]$. The passage of the inhibitor into the cell through the cell membrane is, therefore, the limiting step. As a consequence, the effectiveness of the approach mainly relies on the physicochemical strategy that is adopted to overcome this obstacle. Naked oligonucleotides including RNAi-based inhibitors have very little chance for a significant cell uptake, mostly due to the highly negative charge. To promote their delivery into the cell, the use of a proper carrier is required. The carrier can mask the anionic groups of the nucleotide backbone while interacting with cell surface moieties, thereby inducing internalization or endocytosis of the RNAi-based inhibitors [34]. Importantly, the specific characteristics and composition of the extracellular matrix should be considered for the choice of the appropriate delivery strategy, especially for the cartilage tissue [35]. Indeed, proteoglycans and fibrous proteins can prevent the diffusion of anionic molecules, or act as competitor during RNAi/carrier assembly, thereby affecting its cellular uptake.

Among the different methods for RNAi delivery into chondrocytes and MSCs (Table 1), liposomal-based systems are extremely popular, being easy to use and widely available as commercial products with different formulations, e.g., INTERFERin ${ }^{\mathrm{TM}}$, Oligofectamine ${ }^{\mathrm{TM}}$ and
Lipofectamine $^{\mathrm{TM}}$ reagents [36-38]. Interestingly, liposome-based systems in combination with scaffolds have been proposed as potential tool for efficient, controlled, and localized RNAi delivery for tissue engineering and cartilage regeneration [39]. Among others, Ollitrault et al. developed a novel method applicable to primary chondrocytes or MSCs, by seeding the cells on collagen sponges prior to transfection of siRNA complexes targeting collagen type 1 and HTRAl, a secreted enzyme that is proposed to regulate the availability of IGFs, to induce chondrogenesis [36]. Unfortunately, lack of colloidal stability, moderate cytotoxicity, and potential immunoresponse restrict the therapeutic value of liposome-based carriers, as well as their in vivo application [40]. Nevertheless, research aimed at overcoming these issues is ongoing. Recently, non-phospholipid liposomes (stereosomes) with single-chain amphiphiles and high content of sterols were proposed as better alternatives to the traditional cationic liposomes. This delivery system was successfully adopted to knockdown the expression of Noggin, a specific antagonist of BMP. Notably, Noggin knockdown in MSCs cultured both in vitro and in vivo promoted osteogenesis and bone repair [41].

Most of the recent developments in non-viral vectors for RNAi delivery into MSCs mainly rely on polymers, often in the form of nanoparticles (NPs). Natural polymers, particularly polysaccharides bearing amine groups (i.e., chitosan), can be used to deliver nucleic acids into MSCs. At the same time, synthetic polymers are commonly used in the effort to optimize the characteristics of these carriers. Various synthetic polymers have been proposed, thanks to their limited cytotoxicity, easy production, and high transfection efficiency [34]. Among them are the cationic polymers poly-L-lysine (PLL) and linear or branched polyethylenimine (PEI), polyamidoamine (PAMAM) dendrimers, and poly(D,L-lactide-co-glycolide) (PLGA). Jeon et al. fabricated PLGA NPs loaded with SOX9 plasmid DNA or protein and coated with PEI and RUNX2 siRNA [21, 42]. The loaded NPs were efficiently internalized by hMSCs, increasing chondrogenic differentiation both in vitro and in vivo. In addition to polymers, cell penetrating/permeable peptides in the form of NPs have been explored as carriers for RNAi delivery. Yan et al. generated and delivered peptidic NPs complexed to $N F-k B$ siRNA as a therapeutic approach to mediate chondroprotective effect by preserving cartilage homeostasis in chondrocytes from patients with osteoarthritis (OA) via $N F-k B$ suppression [43].

Water soluble quantum dot (QDs)-based nanocarriers were initially developed as tools for investigating cellular events [44], and now represent an interesting option for RNAi delivery into chondrocytes and MSCs. QDs can be functionalized with different moieties (e.g., Arg-Gly-Asp 
Table 1 Relevant non-viral systems for the delivery of RNAi into human cells for chondrogenesis

\begin{tabular}{|c|c|c|c|c|c|}
\hline Delivery method & & Carrier & Target & Human cells & References \\
\hline \multirow[t]{13}{*}{ Lipid-based delivery systems } & $\uparrow$ Easy to prepare & INTERFERin $^{\text {TM }}$ & Collagen I, HTRA1 & Chondrocytes & {$[36]$} \\
\hline & $\uparrow$ Cost-effective & Oligofectamine $^{\mathrm{TM}}$ & ANGPTL4 & MSCs & {$[37]$} \\
\hline & $\downarrow$ Cytotoxicity & Lipofectamine & MMP13 & Chondrocytes & [117] \\
\hline & $\downarrow$ Low efficiency & $2000^{\mathrm{TM}}$ & miR-30a & Chondrocytes & {$[38]$} \\
\hline & $\downarrow$ Immunoresponse & & circRNA-CER & Chondrocytes & {$[108]$} \\
\hline & & & SLUG & MSCs & {$[61]$} \\
\hline & & & ADAMTS5 & Chondrocytes & [118] \\
\hline & & Lipofectamine & NR1D1, BMAL1 & Chondrocytes & [119] \\
\hline & & RNAiMax $^{\mathrm{TM}}$ & $\operatorname{miR}-222$ & MSCs & [102] \\
\hline & & & Raptor & MSCs & {$[120]$} \\
\hline & & & $\operatorname{miR}-221$ & MSCs & {$[32,60]$} \\
\hline & & $\begin{array}{l}\text { Lipofectamine } \\
\text { LTX }^{\mathrm{TM}}\end{array}$ & $\operatorname{miR}-495$ & MSCs & [94] \\
\hline & & XtremeGENE $^{\mathrm{TM}}$ & AIMP1 & Chondrocytes & {$[23]$} \\
\hline \multirow[t]{2}{*}{ Electroporation } & $\uparrow$ Very effective & Amaxa Nucleofector ${ }^{\mathrm{TM}}$ & RUNX2 & Chondrogenic progenitor cells & {$[53]$} \\
\hline & $\begin{array}{l}\uparrow \text { Reproducible } \\
\downarrow \text { Cell damage }\end{array}$ & Technology & MEK5, ERK5 & Multipotent progenitor cells & {$[66]$} \\
\hline \multirow[t]{5}{*}{ Nanoparticles (NP) } & $\uparrow$ Very effective & LNCs, Span $80^{\mathrm{TM}}$ & REST & MSCs & [121] \\
\hline & $\uparrow$ Limited toxicity & PLGA & RUNX2 & MSCs & {$[21,42]$} \\
\hline & $\downarrow$ High costs & p5RHH peptide & NF-kB & Chondrocytes & {$[43]$} \\
\hline & & Chitosan & MMP3/13 & Chondrocytes & {$[122]$} \\
\hline & & MNP/PEI & miR-335 & MSCs & {$[123]$} \\
\hline \multirow[t]{2}{*}{ Quantum dot (QD) } & $\uparrow$ Very effective & QD-SMCC & SOX9 & MSCs & {$[46]$} \\
\hline & $\begin{array}{l}\uparrow \text { Traceability } \\
\downarrow \text { Cytotoxicity }\end{array}$ & RGD- $\beta$-CD-QD & RUNX2 & MSCs & {$[45]$} \\
\hline Extracellular vesicles (EV) & $\begin{array}{l}\uparrow \text { Non-immunogenic } \\
\uparrow \text { Stability } \\
\downarrow \text { Expensive }\end{array}$ & HEK293T (EV) & GFP & HUVEC, MSCs & [47] \\
\hline
\end{tabular}

peptide and PEG) to maximize cell uptake, biocompatibility, and targeting capacity. Interestingly, $X u$ et al. developed multifunctional QD-based nanocarriers to enhance chondrogenic differentiation and simultaneously suppress hypertrophy of human MSCs [45]. The resulting construct was capable of carrying the hydrophobic chondrogenic inducer kartogenin while binding a siRNA against the pro-hypertrophic regulator $R U N X 2$ via interaction with the Arg-Gly-Asp peptide. $W u$ et al. developed QDs functionalized with sulfosuccinimidyl-4-(N-maleimidomethyl) cyclohexane-1-carboxylate and fluorescently labeled to generate a novel traceable carrier for siRNA molecules. The system was successfully applied to transfect SOX9 siRNA into hMSCs, also allowing non-invasive imaging of siRNA transport both in vitro and in vivo [46].

Further strategies for siRNA delivery were recently introduced thanks to the increasing knowledge on membrane vesicles. Mounting evidence suggests that extracellular vesicles (EV), particularly exosomes, play a crucial role in the transfer of RNA molecules between cells as part of cell communication processes. Different encapsulation approaches have been explored for loading exosomes with DNA or siRNA molecules [47, 48]. Thus, exosomes represent interesting natural carriers potentially exploitable for the delivery of RNAi to a variety of cell types and tissues, including cartilage. Among membrane vesicles-based delivery systems, nanoghosts derived from MSCs are currently under investigation [49, 50]. Interestingly, nanoghosts exhibit inherent targeting capabilities, versatile loading capacity, and immuno evasiveness, making them highly attractive for the development of novel gene silencing-based strategies.

\section{Identifying candidate targets for gene silencing to promote chondrogenesis}

Through the gene silencing approach, numerous scenarios have been explored, including increase of chondrogenic potential of cell populations, stabilization of the 
differentiated phenotype, or improvement of cell survival and anabolic properties. This has led to the identification of many anti-chondrogenic factors that can be potentially targeted in primary cell populations to promote cartilage tissue repair in vivo. Since many factors and complex networks of interactions are responsible for the regulation of the chondrogenic potential, different classes of candidate targets need to be considered. These factors include intracellular molecules, e.g., transcriptional (co-)regulators, matrix components, extracellular signaling molecules, and non-coding RNAs.

\section{Silencing of transcription factors}

Transcription factors (TFs) have long been considered as the central regulators of gene expression and, as such, among the major drivers of cell differentiation and production of ECM. While many TFs have been shown to exert a negative role with respect to chondrogenesis and cartilage production [51], only few have been validated in primary chondroprogenitors or chondrocytes for gene silencing approaches aimed at inducing chondrogenesis (Table 2).

RUNX2 is the best known chondroinhibitory TF during the commitment of mesenchymal progenitors, as it competes with SOX9 to induce osteogenic determination. It also promotes the terminal differentiation of chondrocytes during the later stages of chondrogenesis, contributing to cartilage hypertrophy and calcification [52]. Attempts have been made to target $R U N X 2$ for the enhancement of the chondrogenic potential, or for inhibiting hypertrophy and improving the stability of the newly formed cartilage. Jeon et al. were able to differentiate hMSCs into chondrocytes in vitro and in vivo by treating the cells with PLGA nanoparticles coated with a RUNX2-targeting siRNA and loaded either with SOX9 plasmid DNA or protein [21, 42]. In other studies, RUNX2 knockdown could significantly enhance the chondrogenic potential of human cartilage progenitor cells [53] and OA-like chondrocytes [54].

TGF- $\beta$-induced factor homeobox 1 (TGIF1) is a highly conserved transcriptional regulator that participates in the transmission of nuclear signals during development and in the adult. It is a transcriptional target of TGF- $\beta$ and activin signaling; moreover, being a transcriptional repressor of SOX9, it was found to be downregulated during chondrogenesis [55]. In vivo implantation of Tgifl-depleted MSCs enhanced fibrocartilage production and healing of tendonto-bone insertion in an animal model of supraspinatus tendon tear-and-repair [56, 57]. Notably, the newly formed tissue displayed stronger expression of chondrogenic proteins and greater maximum load at failure and stiffness, performing better both histologically and functionally. SHOX2 is another member of the homeobox protein family. Interestingly, Shox 2 deletion in early chondrocytes stimulated hypertrophy, while deletion in MSCs enhanced early chondrogenesis due to increased BMP activity, without signs of hypertrophic maturation [58].

Epithelial-to-mesenchymal transition (EMT) regulators play a decisive role in chondrogenesis. These proteins are directly responsible for the determination and stability of the cell phenotype, as they regulate the expression of lineage-specific transcription factors (e.g. SOX9 and RUNX2) and adhesion molecules. Among the EMT-regulators, TWIST1 and SLUG/SNAIL2 were validated as targets for

Table 2 Validated targets for gene silencing strategies aimed at enhancing chondrogenesis-transcription factors

\begin{tabular}{|c|c|c|c|}
\hline Target & Main function & Biological effect of gene silencing & References \\
\hline \multirow[t]{3}{*}{ RUNX2 } & \multirow[t]{3}{*}{$\begin{array}{l}\text { Osteoblast } \\
\text { differentiation }\end{array}$} & $\begin{array}{l}\text { Chondrogenesis of hMSCs with reduced expression of collagen I and osteogenic markers in vitro and } \\
\text { after injection in mice }\end{array}$ & {$[21,42]$} \\
\hline & & $\begin{array}{l}\text { Enhanced expression of SOX9 and increased synthesis of cartilage matrix (collagen II, aggrecan) in } \\
\text { chondrogenic progenitor cells. Reduced expression of collagen I and catabolic enzymes (MMP13, } \\
\text { aggrecanase-2/ ADAMTS5) }\end{array}$ & {$[53]$} \\
\hline & & $\begin{array}{l}\text { Enhanced expression of SOX9 and collagen II and loss of collagen I in chondrocytes derived from } \\
\text { DDR-1 deficient mice (OA model) }\end{array}$ & {$[54]$} \\
\hline TGIF1 & $\begin{array}{l}\text { Embryonic } \\
\text { development }\end{array}$ & $\begin{array}{l}\text { Enhanced chondrogenesis of rat tendon and bone marrow-derived MSCs in vitro. Improved } \\
\text { fibrocartilage production and healing of bone-to-tendon insertion after in vivo implantation }\end{array}$ & {$[55-57]$} \\
\hline SHOX2 & $\begin{array}{l}\text { Embryonic } \\
\text { development }\end{array}$ & $\begin{array}{l}\text { Chondrogenesis of mouse MSCs in the absence of chondro-stimulation without transition to the } \\
\text { hypertrophic stage }\end{array}$ & {$[58]$} \\
\hline TWIST1 & EMT & $\begin{array}{l}\text { Increased formation of chondrogenic nodules and expression of chondrogenic markers during } \\
\text { micromass culture of murine limb bud mesenchymal cells }\end{array}$ & {$[59]$} \\
\hline SLUG & EMT & $\begin{array}{l}\text { Chondrogenesis of human bone marrow or Wharton's jelly-derived hMSCs, and enhanced production } \\
\text { of cartilage ECM onto HYAFF-11 scaffold }\end{array}$ & {$[60,61]$} \\
\hline $\mathrm{p} 53$ & Cell cycle & $\begin{array}{l}\text { Increased proliferation and expression of SOX9, collagen II, and aggrecan in progenitor cells isolated } \\
\text { from human articular cartilage }\end{array}$ & {$[124]$} \\
\hline
\end{tabular}


enhancing the chondrogenic potential [59-61]. We previously showed that treating hMSCs from different sources with a siRNA against $S L U G$ induced chondrogenesis and production of cartilage ECM in a 3D-microenvironment. Interestingly, even in the absence of TGF- $\beta, S L U G$ depletion alone was sufficient to direct hMSCs towards the chondrocyte lineage [61].

\section{Silencing of intracellular co-regulators and enzymes}

While transcription factors are traditionally regarded as the major drivers of differentiation, the role of transcriptional co-regulators, cell cycle regulators and intracellular enzymes should not be underestimated. Different factors belonging to these families have been proposed as candidate targets for gene silencing to improve chondrogenic differentiation (Table 3).

Cell cycle regulators are responsible for the integration of diverse extracellular signals and their participation in coordinated proliferation and differentiation of chondrocytes [62]. Thus, manipulation of these genes may greatly affect chondrogenesis. Knockdown of the transcriptional coactivator YAP in articular chondrocytes increased the expression of Sox9, collagen type II, and aggrecan, with a concomitant decrease of collagen type I [63]. The cyclindependent kinase inhibitor p16 is overexpressed in human OA chondrocytes, and its knockdown induced proliferation and recovered the expression of collagen type II and aggrecan [64]. Similarly, lentiviral-mediated knockdown of p21 in murine induced pluripotent stem cells stimulated proliferation during expansion and increased matrix production while limiting the synthesis of collagen type I and X [22]. Silencing of the cell growth regulator Gadd45b blocked terminal differentiation and expression of catabolic enzymes and collagen type $\mathrm{X}$ in 3D-pellet cultured murine chondrocytes [65]. Importantly, this study proposed Gadd $45 b$ as a critical regulator of the hypertrophic transition, hence, a relevant target to stabilize the chondrogenic phenotype of implanted cells.

Within the class of intracellular enzymes, four protein kinases were successfully targeted for the enhancement of the chondrogenic potential, i.e., mitogen-activated protein kinase kinase 5 (MEK5), extracellular signal-regulated kinase 5 (ERK5), and the IkB kinases (IKK) $\alpha / \beta$. siRNAmediated knockdown of MEK5 and ERK5 in hMSCs enhanced the production of glycosaminoglycans (GAGs), cartilage ECM proteins and pro-chodrogenic regulators, even in the absence of TGF- $\beta$ supplementation [66]. Silencing of both $I K K$ kinases in human OA chondrocytes led to increased production of cartilage matrix and concomitant inhibition of collagen type $\mathrm{X}$ and reduced formation of calcium deposits [67]. To date, targeting of 3 non-kinase intracellular enzymes has been reported, i.e., the p53-inducible ribonucleotide reductase (p53R2), the

Table 3 Validated targets for gene silencing strategies aimed at enhancing chondrogenesis—intracellular co-regulators and enzymes

\begin{tabular}{|c|c|c|c|}
\hline Target & Main function & Biological effect of gene silencing & References \\
\hline YAP & $\begin{array}{l}\text { Proliferation and } \\
\text { apoptosis }\end{array}$ & $\begin{array}{l}\text { Increased expression of SOX9, collagen II and aggrecan, and decreased collagen I in rat articular } \\
\text { chondrocytes }\end{array}$ & {$[63]$} \\
\hline p16 & Cell cycle & $\begin{array}{l}\text { Enhanced proliferation of OA chondrocytes and recovered expression of collagen II and } \\
\text { aggrecan without increase of collagen I. Enhanced response to TGF- } \beta 1 \text { and protection from } \\
\text { inflammatory stimuli (IL-1 } \alpha \text { ) }\end{array}$ & [64] \\
\hline $\mathrm{p} 21$ & Cell cycle & $\begin{array}{l}\text { Enhanced proliferation during expansion and collagen II and GAGs production during pellet } \\
\text { culture of murine iPS. Maintenance of the chondrogenic potential of extensively passaged } \\
\text { cells. Suppression of collagen I and X }\end{array}$ & {$[22]$} \\
\hline GADD $45 \beta$ & Cell cycle & $\begin{array}{l}\text { Suppressed terminal differentiation and expression of MMP13 in murine rib growth plate } \\
\text { chondrocytes }\end{array}$ & {$[65]$} \\
\hline $\begin{array}{l}\text { ERK5, } \\
\text { MEK5 }\end{array}$ & $\begin{array}{c}\text { Proliferation and } \\
\text { differentiation }\end{array}$ & $\begin{array}{l}\text { Enhanced expression of SOX5, SOX6, SOX9, collagen II, aggrecan, and GAGs production in } \\
\text { hMSCs. Enhancement of the chondrogenic potential even in the absence of TGF- } \beta\end{array}$ & {$[66]$} \\
\hline $\mathrm{IKK} \alpha / \beta$ & Inflammation & $\begin{array}{l}\text { Increased cartilage ECM production (collagen II, GAGs) and suppression of terminal } \\
\text { differentiation in OA chondrocytes. Inhibition of the IL- } 1 \beta \text { mediated increase of MMP13 }\end{array}$ & {$[67]$} \\
\hline $\mathrm{p} 53 \mathrm{R} 2$ & DNA repair & Increased production of collagen II, aggrecan and GAGs in OA chondrocytes after tensile strain. & {$[68]$} \\
\hline PHD2 & Response to hypoxia & $\begin{array}{l}\text { Upregulation of SOX9 and increased production of the cartilage ECM components collagen II, } \\
\text { IX, XI, and aggrecan under normoxic or hypoxic conditions }\end{array}$ & [69] \\
\hline KDM2A & $\begin{array}{l}\text { Chromatin } \\
\text { remodeling }\end{array}$ & Enhanced chondrogenesis of apical papilla-derived hMSCs & {$[70]$} \\
\hline Raptor & Proliferation & $\begin{array}{l}\text { Enhanced chondrogenesis of amniotic fluid-derived hMSCs with increased AKT activation, } \\
\text { upregulation of HIF- } 2 \alpha \text { and increased SOX9 and collagen II abundance }\end{array}$ & [120] \\
\hline
\end{tabular}


Table 4 Validated targets for gene silencing strategies aimed at enhancing chondrogenesis-matrix and secreted proteins

\begin{tabular}{|c|c|c|c|}
\hline Target & Main function & Biological effect of gene silencing & References \\
\hline \multirow[t]{2}{*}{ Collagen I } & $\begin{array}{l}\text { ECM structural } \\
\text { component }\end{array}$ & $\begin{array}{l}\text { Enhanced chondrogenic potential of human dedifferentiated chondrocytes cultured in } \\
\text { collagen sponges. Enhanced production of collagen II and aggrecan after subcutaneous } \\
\text { implantation in mice }\end{array}$ & {$[36]$} \\
\hline & & Increased synthesis of collagen II, aggrecan, COMP and GAGs in pig synovial MSCs & [77] \\
\hline HTRA1 & $\begin{array}{l}\text { Regulation of the } \\
\text { availability of IGFs }\end{array}$ & $\begin{array}{l}\text { Enhanced chondrogenic potential of human dedifferentiated chondrocytes cultured in } \\
\text { collagen sponges. Enhanced production of collagen II and aggrecan after subcutaneous } \\
\text { implantation in mice }\end{array}$ & {$[36]$} \\
\hline Decorin & $\begin{array}{l}\text { ECM structural } \\
\text { component }\end{array}$ & Increased expression of SOX9, biglycan, and aggrecan in hMSCs & [78] \\
\hline Lumican & $\begin{array}{l}\text { ECM structural } \\
\text { component }\end{array}$ & Augmented production of collagen II and increased fibril diameter in bovine chondrocytes & [79] \\
\hline Asporin & $\begin{array}{l}\text { ECM structural } \\
\text { component }\end{array}$ & Increased expression of collagen II, aggrecan, and TGF- $\beta 1$ in human chondrocytes & {$[80]$} \\
\hline $\begin{array}{l}\text { Aggrecanase- } \\
\quad 1 / 2\end{array}$ & $\begin{array}{l}\text { Catabolism of cartilage } \\
\text { ECM }\end{array}$ & $\begin{array}{l}\text { Enhanced proliferation, abundance of GAGs and total collagen, and expression of collagen } \\
\text { II and aggrecan in rat chondrocytes cultured on a chitosan-gelatin scaffold }\end{array}$ & [81] \\
\hline MMP2 & $\begin{array}{l}\text { Catabolism of cartilage } \\
\text { ECM }\end{array}$ & $\begin{array}{l}\text { Increased expression of fibronectin, integrin } \alpha 5 \text { and } \beta 1 \text { in chicken limb bud mesenchymal } \\
\text { cells. Enhanced precartilage condensation and GAGs production }\end{array}$ & {$[82]$} \\
\hline VEGF & $\begin{array}{l}\text { Vasculogenesis and } \\
\text { angiogenesis }\end{array}$ & $\begin{array}{l}\text { Enhanced production of collagen II, aggrecan and chondromodulin } 1 \text { during pellet culture } \\
\text { of chondrocytes. Suppression of RUNX2, MMP13 and ALP. Protection from pro- } \\
\text { hypertrophic stimuli (TNF } \alpha \text { ) }\end{array}$ & [83] \\
\hline AIMP1 & $\begin{array}{l}\text { Angiogenesis and } \\
\text { inflammation }\end{array}$ & $\begin{array}{l}\text { Enhanced production of collagen II, aggrecan and GAGs in dedifferentiated and OA } \\
\text { chondrocytes in vitro. Enhanced cartilage tissue formation in vivo }\end{array}$ & {$[23]$} \\
\hline ANGPTL4 & Lipid metabolism & $\begin{array}{l}\text { Increased expression of collagen II and aggrecan, and suppression of MMP1, } 3 \text { and } 13 \text { in } \\
\text { hMSCs }\end{array}$ & {$[37]$} \\
\hline
\end{tabular}

prolyl hydroxylase domain-containing protein 2 (PHD2), and the lysine demethylase 2A (KDM2A) [68-70]. These studies not only identified novel candidate targets for the induction of chondrogenesis, but also highlighted the feasibility of manipulating cellular oxygen sensors (PHD2) and the epigenetic machinery (KDM2A) to guide the chondrogenic process and cartilage synthesis.

Additional intracellular targets have been suggested, but the effectiveness to induce production of cartilage ECM by silencing these genes needs to be investigated. Among them are the RNA-binding protein TTP [71], the phospholipase $\mathrm{C} \gamma 1$ [72], the Ras-related proteins RALA [73] and RAB3B [74], the components of the ubiquitin-proteasome pathway E6-AP and UBC9 [75], the anti-apoptotic protein BRE [76], and the actin filament-associated protein AFAP [74].

\section{Silencing of matrix and secreted proteins}

As described so far, the targeting of intracellular regulators by gene silencing aims to re-programme the cell behavior to enhance the chondrogenic phenotype. At the same time, a careful manipulation of the extracellular milieu may offer an attractive alternative, in the effort to remodel the joint microenvironment for optimal cartilage repair. This goal may be achieved by suppression of (a) matrix components whose presence is not desirable in the newly formed tissue, (b) pro-catabolic enzymes, and (c) anti-chondrogenic extracellular signals (Table 4).

Suboptimal cartilage repair normally leads to the production of tissue containing abundant collagen type I, in addition to collagen type II. This is a serious concern as such newly formed fibrocartilage lacks the desired mechanical strength that is typical of hyaline cartilage and required to repair joint lesions. Encouragingly, different studies have succeeded in circumventing this issue by silencing collagen type I [36, 77]. Remarkably, this strategy did not only prevent production of collagen type I, but also enhanced the synthesis of typical components of cartilage matrix (collagen type II, aggrecan, GAGs) both in vitro and in vivo. Suppression of collagen type I may, therefore, help in preventing fibrogenesis while improving the hyaline features of the newly synthesized ECM. Interestingly, other ECM proteins have been targeted to improve the quality of neocartilage produced by chondrocytes and hMSCs, i.e., decorin [78], lumican [79], and asporin [80].

MMPs and aggrecanases are key degradative enzymes in articular cartilage. Strong evidence suggests that their knockdown via gene silencing can inhibit matrix degradation 
Table 5 Validated targets for gene silencing strategies aimed at enhancing chondrogenesis-microRNAs

\begin{tabular}{|c|c|c|}
\hline Target & Biological effect of gene silencing & References \\
\hline miR-30a & $\begin{array}{l}\text { Increased expression of SOX9, collagen II, and GAGs production in human chondrocytes. Protection } \\
\text { from inflammatory stimuli (IL-1 } \beta \text { ) }\end{array}$ & [38] \\
\hline miR-145 & Increased expression of SOX9 in human chondrocytes & [91] \\
\hline $\operatorname{miR}-199 \mathrm{a}$ & Increased expression of SOX9, collagen II, and aggrecan in human chondrocytes and MSCs & {$[93,125]$} \\
\hline $\operatorname{miR}-495$ & Enhanced the TGF- $\beta 3$-mediated chondrogenesis of hMSCs & [94] \\
\hline $\operatorname{miR}-1247$ & Increased expression of SOX9 and collagen II in human chondrocytes & [95] \\
\hline miR-194 & $\begin{array}{l}\text { Enhanced chondrogenesis of adipose tissue derived hMSCs. Increased expression of collagen II, IX, } \\
\text { XI, aggrecan, and COMP }\end{array}$ & [96] \\
\hline $\operatorname{miR}-34 a$ & $\begin{array}{l}\text { Increased synthesis of cartilage ECM (collagen II, GAGs) by limb bud mesenchymal cells. Protection } \\
\text { of human chondrocytes from inflammatory stimuli (IL-1 } \beta \text { ) }\end{array}$ & {$[98,100]$} \\
\hline miR-142 & Increased cell viability, proliferation, migration and precartilage condensation of mesenchymal cells & [99] \\
\hline $\operatorname{miR}-375$ & Increased proliferation, migration and precartilage condensation of mesenchymal cells & [97] \\
\hline miR-99a & $\begin{array}{l}\text { Promotion of early chondrogenesis of rat MSCs with increased production of cartilage ECM (collagen } \\
\text { II, aggrecan, GAGs) }\end{array}$ & {$[101]$} \\
\hline $\operatorname{miR}-193 b$ & Increased expression of SOX9, collagen II and aggrecan in human chondrocytes & [93] \\
\hline $\operatorname{miR}-200 \mathrm{a}$ & $\begin{array}{l}\text { Enhanced chondrogenesis in MCC cells and organ cultures, with increased levels of SOX9 and } \\
\text { collagen II }\end{array}$ & [24] \\
\hline $\operatorname{miR}-221$ & $\begin{array}{l}\text { In vitro chondrogenesis of hMSCs in the absence of growth factors and without progression to } \\
\text { hypertrophy. Enhanced hMSCs-mediated in vivo cartilage repair }\end{array}$ & {$[32,60]$} \\
\hline $\operatorname{miR}-222$ & $\begin{array}{l}\text { Enhanced chondrogenesis and osteogenesis of hMSCs in vitro. Improved angiogenesis and bone } \\
\text { union and healing in vivo }\end{array}$ & [102] \\
\hline circRNA-CER & Increased expression of collagen II and aggrecan in human OA chondrocytes. Suppression of MMP13 & [108] \\
\hline lncRNA-CIR & $\begin{array}{l}\text { Increased expression of collagen I, II, aggrecan and GAGs production in human OA chondrocytes. } \\
\text { Suppression of MMP13 and ADAMTS5 }\end{array}$ & [109] \\
\hline
\end{tabular}

and help to preserve the integrity of articular cartilage. Lentiviral-mediated knockdown of aggrecanases in primary chondrocytes cultured on a chitosan-gelatin scaffold facilitated the in vitro formation of engineered cartilage [81]. In a second study, treatment with MMP2 siRNA increased the expression of adhesion molecules in chicken limb mesenchymal cells, overall stimulating precartilage condensation, chondrogenesis, and production of GAGs [82].

Secreted proteins that function as anti-chondrogenic extracellular signals are susceptible of gene silencing-mediated manipulation. Interesting findings concern aminoacyl tRNA synthetase complex interacting multifunctional protein 1 (AIMP1), angiopoietin-like 4 (ANGPTL4), and VEGF. AIMP1 negatively regulates the TGF- $\beta$ signaling by preventing SMAD2/3 phosphorilation, and a siRNA against $A I M P 1$ was effective in rescuing the chondrogenic potential of dedifferentiated and OA human chondrocytes, in vitro and in vivo [23]. Treatment of hMSCs with a specific siRNA against ANGPTLA prior to chondrogenesis increased the expression of collagen type II and aggrecan, while repressing the expression of MMPs [37]. Finally, suppression of VEGF was showed to enhance the chondrogenic potential of human chondrocytes, while providing protection from hypertrophy-inducing stimuli [83].
Other candidate extracellular targets have been proposed, but extensive investigations are missing, i.e., IHH [84], NOTCH1 [85], the Wnt-related proteins DKK3 [74] and WNT5A [86], OB-cadherin [87], Fibulin-3 [88], and the orphan G-protein coupled receptor RDC1 [89].

\section{Silencing of non-coding RNAs}

Increasing evidence demonstrates that non-coding RNAs, and especially microRNAs, are crucial for the homeostasis and integrity of articular cartilage [90]. Thanks to their ability to simultaneously inhibit the expression of many genes, microRNAs exert a tight and complex control on both chondrogenic differentiation and maintenance of cartilage ECM. This makes them highly attractive targets for gene manipulation strategies (Table 5).

Different microRNAs exert an anti-chondrogenic role by direct repression of SOX9. Among them are $m i R-30 a$ [38], miR-145 [91, 92], miR-199a [93], miR-495 [94], and $m i R-1247$ [95]. Silencing of these microRNAs in human articular chondrocytes or hMSCs led to relieved repression of SOX9, whose increased levels stimulate the synthesis of cartilage ECM components. A second member of the SOX-trio, SOX5, was identified as the direct target of miR-194. Suppression of $m i R-194$ in 
hMSCs enhanced chondrogenesis and production of cartilage ECM [96].

$m i R-34 a, m i R-142$, and $m i R-375$ were found to be downregulated during the chondrogenesis of limb bud mesenchymal cells [97-100]. miR-34a silencing induced the expression of collagen type II and GAGs production, while inhibition of $m i R-142$ or $m i R-375$ by peptide nucleic acid (PNA)-based inhibitors promoted proliferation, migration, and precartilage condensations of mesenchymal cells in vitro. Recently, the BMP receptor type 2, a crucial regulator of endochondral bone formation, was identified as the direct target of miR-99a. Knockdown of $m i R-99 a$ led to promotion of early chondrogenesis of rat MSCs, and increased production of cartilage ECM [101]. Umeda et al. identified miR$200 a$ as a major regulator of the formation of cartilage during mandibular condylar cartilage (MCC) development. Transfection of antimiR-200a in MCC cells or organ culture positively influenced chondrogenesis, inducing the expression of $\operatorname{Sox} 9$ and collagen type II [24].

We previously characterized $m i R-221$ as a novel regulator of chondrogenesis. Silencing miR-221 in hMSCs proved effective and sufficient to induce differentiation into chondrocytes, without requiring supplementation with growth factors [32]. Notably, seeding of miR-221-depleted hMSCs in cartilage defects led to enhanced cartilage repair in vivo, providing a proof of concept for the implantation of miRNA-depleted hMSCs for improved cartilage repair. Interestingly, Yoshizuka et al. showed that silencing of the paralogue of $m i R-221, m i R-222$, promoted chondrogenesis, and osteogenesis of hMSCs, as well as angiogenesis and bone healing in a rat fracture model [102].

Additional microRNAs have been shown to inhibit the chondrogenesis of hMSCs, i.e., miR-29a [103], miR-138 [104], $m i R-181 b$ [105], and $m i R-499 a$ [106]. However, the feasibility of targeting these microRNAs for the guidance of chondrogenesis still needs to be assessed.

Finally, other types of non-coding RNAs have been shown to regulate chondrogenesis, thereby providing additional candidate targets for gene silencing. Circular RNAs (circRNAs) and long non-coding RNAs (lncRNAs) are large classes of non-coding RNAs, not completely characterized, and whose role in cartilage homeostasis and disease is still obscure [107-109]. cir$c R N A-C E R$ and IncRNA-CIR were recently found to be overexpressed in OA cartilage. Interestingly, silencing of circRNA-CER or IncRNA-CIR in OA chondrocytes led to enhanced expression of pro-chondrogenic genes and suppression of catabolic enzymes (MMPs and aggrecanases) [108, 109].

\section{Concluding remarks and open questions}

The idea of producing hMSCs depleted of anti-chondrogenic factors ("silenced hMSCs") represents an intriguing challenge from different perspectives. On one hand, "silenced hMSCs" represent an ideal system to elucidate and validate the function of a gene or a microRNA in the context of chondrogenesis and cartilage repair. On the other, they may provide a novel therapeutic tool for enhanced cartilage repair (Fig. 1). In this review, we present the current knowledge related to anti-chondrogenic genes that can be targeted to enhance the therapeutic potential of primary chondrogenic cells. While a growing body of evidence thus supports the great potential of RNAi-based approaches in this field, diverse issues remain to be addressed, in the effort to generate functional and durable articular cartilage, and to address patient-specific needs.

Cartilage regeneration is not regulated by simple mechanisms supported by one factor, but rather by the interplay of multiple biological factors and downstream signaling cascades [110]. To date, these aspects are not fully understood. Thus, researchers are wondering how to generate the best "silenced hMSCs" for efficient cartilage repair. Which is the anti-chondrogenic factor that once silenced can guarantee the best effect on cartilage formation? While this certainly depends on the biological context and the size of the damage to be repaired, only further experiments with more complex models of cartilage defect will give an adequate response. In this regard, it is imperative to point out that extensive in vivo studies are still lacking, and further efforts are needed to unveil the true potential of gene silencing approaches for cartilage repair.

First of all, it is essential to understand how the "silenced hMSCs" are able to influence the microenvironment once implanted, and how the local pathophysiological conditions may affect the performance of the "silenced hMSCs". It is well established that subchondral bone [111], synovium [112] and articular fat tissue [113] may greatly affect the process of chondrogenesis and cartilage repair. Histological and molecular analysis detecting the tissue response and changes that occur following implantation could help in optimizing the "silenced hMSCs" for the repair of a specific type of damage. This aspect deserves particular attention and directly relates to the achievement of a "dynamic state of communication" between endogenous and implanted cells (Fig. 1), and ultimately to the formation of well-organized neocartilage with proper biomechanical and functional properties [114]. In this context, a major contribution will derive from preclinical studies implanting "silenced hMSCs" into critical 


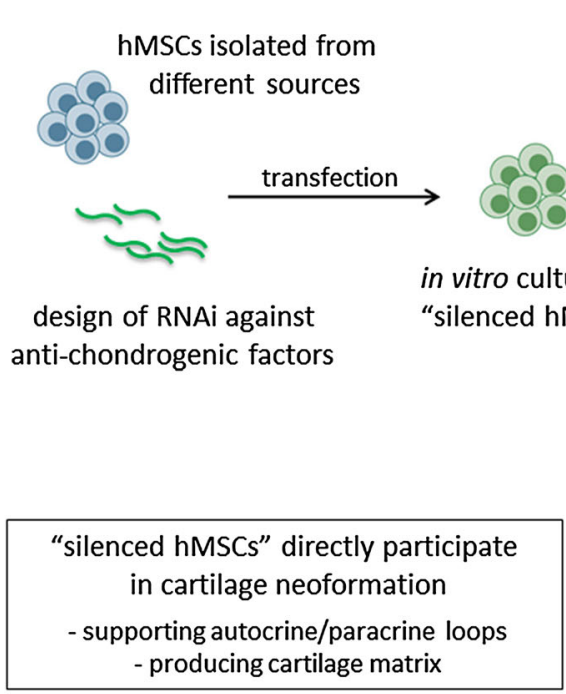

Fig. 1 Schematic representation of the production and transplantation of "silenced hMSCs" for improved cartilage repair. hMSCs can be collected from different sources including adult niches (e.g., bone marrow and adipose tissue) or perinatal tissues (e.g., placenta, amnios, and Wharton's jelly of umbilical cord). Following transfection with RNAi molecules, "silenced hMSCs" with enhanced chondrogenic and therapeutic potential are generated. The cells are cultured in vitro for a certain amount of time to obtain an

size chondral or osteochondral defects in large animal models, such as the equine model, that better mimic the human physiology.

Another important aspect is the combination of the "silenced hMSCs" with exogenous scaffolds. This is particularly relevant, since delivering a sufficient amount of RNAi molecules to cells is a notoriously difficult task. An important branch of biomaterials science is aimed at studying the optimal combination of the cells with convenient chemically or physically modified scaffolds. This can sustain the gene silencing process while providing a favourable microenvironment for the "silenced hMSCs" at the defect site. In addition, the presence of a scaffold can be important for the newly formed cartilage to achieve the proper biomechanical properties. At the same time, it should be considered that side effects due to the presence of exogenous materials, in terms of short- and long-term foreign body reaction, may eventually arise.

Finally, it is important to mention that accumulated evidence is pushing research in the direction of endogenous cartilage repair. It is well established that bone marrow and synovium-derived MSCs have the ability to migrate to the site of cartilage damage, and initiate the repair of partial or full-thickness cartilage defects $[115,116]$. Based on this concept, endogenous repair strategies aim to direct the migration of autologous MSCs toward the site of damage, and to induce in situ

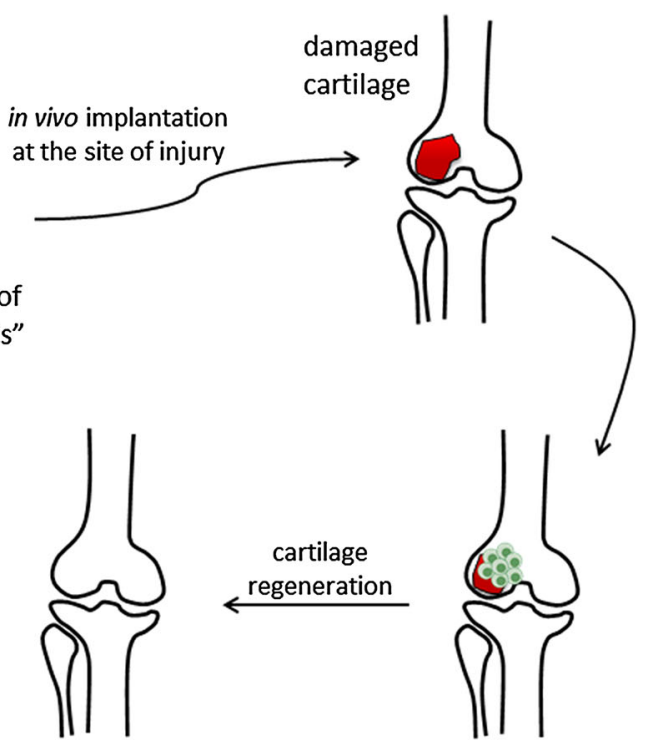

implantable construct, possibly by combination with a scaffold. Different parameters (cell number, oxygen concentration, use of a bioreactor) may be modified to optimize culture conditions and to mimic as much as possible the physiological microenvironment. Following implantation into the site of injury, neoformation of cartilage can be achieved, and tissue functionality can be restored as a result of diverse events potentially supported by the "silenced hMSCs"

chondrogenic differentiation for local tissue repair. In such a context, the targeting of autologous cells with RNAi molecules against anti-chondrogenic factors, previously validated using the approaches described in this review, would represent an intriguing option to accelerate and direct the process of endogenous repair.

Acknowledgements A.L. is funded by the European Union's Horizon 2020 research and innovation programme under Marie Sklodowska Curie Grant agreement No 642414. R.N. is supported by the VENI Grant by STW (13659). The authors are grateful to Dr. E. J. Farrell, Department of Oral and Maxillofacial Surgery, Erasmus MC, University Medical Center, for English revision of the manuscript.

\section{References}

1. Musumeci G, Aiello FC, Szychlinska MA, Di Rosa M, Castrogiovanni P, Mobasheri A (2015) Osteoarthritis in the XXIst century: risk factors and behaviours that influence disease onset and progression. Int J Mol Sci 16(3):6093-6112

2. Akkiraju H, Nohe A (2015) Role of chondrocytes in cartilage formation, progression of osteoarthritis and cartilage regeneration. J Dev Biol 3(4):177-192

3. Brittberg M (2015) Cellular and acellular approaches for cartilage repair: a philosophical analysis. Cartilage 6(2 Suppl):4S$12 \mathrm{~S}$

4. Jayasuriya CT, Chen Y, Liu W, Chen Q (2016) The influence of tissue microenvironment on stem cell-based cartilage repair. Ann N Y Acad Sci 1383(1):21-33

5. Yamasaki S, Mera H, Itokazu M, Hashimoto Y, Wakitani S (2014) Cartilage repair with autologous bone marrow 
mesenchymal stem cell transplantation: review of preclinical and clinical studies. Cartilage 5(4):196-202

6. Li KC, Hu YC (2015) Cartilage tissue engineering: recent advances and perspectives from gene regulation/therapy. Adv Healthc Mater 4(7):948-968

7. Fellows CR, Matta C, Zakany R, Khan IM, Mobasheri A (2016) Adipose, bone marrow and synovial joint-derived mesenchymal stem cells for cartilage repair. Front Genet 7:213

8. Anz AW, Bapat A, Murrell WD (2016) Concepts in regenerative medicine: past, present, and future in articular cartilage treatment. J Clin Orthop Trauma 7(3):137-144

9. de Windt TS, Vonk LA, Slaper-Cortenbach IC, van den Broek MP, Nizak R, van Rijen MH, de Weger RA, Dhert WJ, Saris DB (2017) Allogeneic mesenchymal stem cells stimulate cartilage regeneration and are safe for single-stage cartilage repair in humans upon mixture with recycled autologous chondrons. Stem Cells 35(1):256-264

10. Baghaban Eslaminejad M, Malakooty Poor E (2014) Mesenchymal stem cells as a potent cell source for articular cartilage regeneration. World J Stem Cells 6(3):344-354

11. Madry H, Cucchiarini M (2011) Clinical potential and challenges of using genetically modified cells for articular cartilage repair. Croat Med J 52(3):245-261

12. Kozhemyakina E, Lassar AB, Zelzer E (2015) A pathway to bone: signaling molecules and transcription factors involved in chondrocyte development and maturation. Development 142(5):817-831

13. Goldring MB (2012) Chondrogenesis, chondrocyte differentiation, and articular cartilage metabolism in health and osteoarthritis. Ther Adv Musculoskelet Dis 4(4):269-285

14. Matta C, Mobasheri A (2014) Regulation of chondrogenesis by protein kinase $\mathrm{C}$ : emerging new roles in calcium signalling. Cell Signal 26(5):979-1000

15. Topol L, Chen W, Song H, Day TF, Yang Y (2009) Sox 9 inhibits Wnt signaling by promoting beta-catenin phosphorylation in the nucleus. J Biol Chem 284(5):3323-3333

16. Lefebvre V, Smits P (2005) Transcriptional control of chondrocyte fate and differentiation. Birth Defects Res C Embryo Today 75(3):200-212

17. Gibson TJ, Seiler M, Veitia RA (2013) The transience of transient overexpression. Nat Methods 10(8):715-721

18. Gyorgy A, Del Vecchio D (2014) Limitations and trade-offs in gene expression due to competition for shared cellular resources. Proceedings of the 53rd IEEE Conference on Decision and Control: http://hdl.handle.net/1721.1/97416

19. Battistella M, Marsden PA (2015) Advances, nuances, and potential pitfalls when exploiting the therapeutic potential of RNA interference. Clin Pharmacol Ther 97(1):79-87

20. Borna H, Imani S, Iman M, Jamalkandi S (2015) Therapeutic face of RNAi: in vivo challenges. Expert Opin Biol Ther 15(2):269-285

21. Jeon SY, Park JS, Yang HN, Lim HJ, Yi SW, Park H, Park KH (2014) Co-delivery of Cbfa-1-targeting siRNA and SOX9 protein using PLGA nanoparticles to induce chondrogenesis of human mesenchymal stem cells. Biomaterials 35(28):8236-8248

22. Diekman BO, Thakore PI, O'Connor SK, Willard VP, Brunger JM, Christoforou N, Leong KW, Gersbach CA, Guilak F (2015) Knockdown of the cell cycle inhibitor p21 enhances cartilage formation by induced pluripotent stem cells. Tissue Eng Part A 21(7-8):1261-1274

23. Ahn J, Kumar H, Cha BH, Park S, Arai Y, Han I, Park SG, Lee SH (2016) AIMP1 downregulation restores chondrogenic characteristics of dedifferentiated/degenerated chondrocytes by enhancing TGF-beta signal. Cell Death Dis 7:e2099
24. Umeda M, Terao F, Miyazaki K, Yoshizaki K, Takahashi I (2015) MicroRNA-200a regulates the development of mandibular condylar cartilage. J Dent Res 94(6):795-802

25. Liew A, Andre FM, Lesueur LL, De Menorval MA, O'Brien T, Mir LM (2013) Robust, efficient, and practical electrogene transfer method for human mesenchymal stem cells using square electric pulses. Hum Gene Ther Methods 24(5):289-297

26. King WJ, Kouris NA, Choi S, Ogle BM, Murphy WL (2012) Environmental parameters influence non-viral transfection of human mesenchymal stem cells for tissue engineering applications. Cell Tissue Res 347(3):689-699

27. Yu X, Murphy WL (2014) 3-D scaffold platform for optimized non-viral transfection of multipotent stem cells. J Mater Chem B Mater Biol Med 2(46):8186-8193

28. Cucchiarini M, Madry H (2014) Use of tissue engineering strategies to repair joint tissues in osteoarthritis: viral gene transfer approaches. Curr Rheumatol Rep 16(10):449

29. Raisin S, Belamie E, Morille M (2016) Non-viral gene activated matrices for mesenchymal stem cells based tissue engineering of bone and cartilage. Biomaterials 104:223-237

30. Abdul Halim NS, Fakiruddin KS, Ali SA, Yahaya BH (2014) A comparative study of non-viral gene delivery techniques to human adipose-derived mesenchymal stem cell. Int J Mol Sci 15(9):15044-15060

31. Mencia Castano I, Curtin CM, Shaw G, Murphy JM, Duffy GP, O'Brien FJ (2015) A novel collagen-nanohydroxyapatite microRNA-activated scaffold for tissue engineering applications capable of efficient delivery of both miR-mimics and antagomiRs to human mesenchymal stem cells. J Control Release 200:42-51

32. Lolli A, Narcisi R, Lambertini E, Penolazzi L, Angelozzi M, Kops N, Gasparini S, van Osch GJ, Piva R (2016) Silencing of antichondrogenic microRNA-221 in human mesenchymal stem cells promotes cartilage repair in vivo. Stem Cells 34(7):1801-1811

33. Li Z, Rana TM (2014) Therapeutic targeting of microRNAs: current status and future challenges. Nat Rev Drug Discov 13(8):622-638

34. Mokhtarzadeh A, Alibakhshi A, Hashemi M, Hejazi M, Hosseini V, de la Guardia M, Ramezani M (2017) Biodegradable nano-polymers as delivery vehicles for therapeutic small noncoding ribonucleic acids. J Control Release 245:116-126

35. Pi Y, Zhang X, Shao Z, Zhao F, Hu X, Ao Y (2015) Intraarticular delivery of anti-Hif-2alpha siRNA by chondrocytehoming nanoparticles to prevent cartilage degeneration in arthritic mice. Gene Ther 22(6):439-448

36. Ollitrault D, Legendre F, Drougard C, Briand M, Benateau H, Goux D, Chajra H, Poulain L, Hartmann D, Vivien D, Shridhar V, Baldi A, Mallein-Gerin F, Boumediene K, Demoor M, Galera P (2015) BMP-2, hypoxia, and COL1A1/HtrA1 siRNAs favor neo-cartilage hyaline matrix formation in chondrocytes. Tissue Eng Part C Methods 21(2):133-147

37. Mathieu M, Iampietro M, Chuchana P, Guerit D, Djouad F, Noel D, Jorgensen C (2014) Involvement of angiopoietin-like 4 in matrix remodeling during chondrogenic differentiation of mesenchymal stem cells. J Biol Chem 289(12):8402-8412

38. Chang T, Xie J, Li H, Li D, Liu P, Hu Y (2016) MicroRNA-30a promotes extracellular matrix degradation in articular cartilage via downregulation of Sox9. Cell Prolif 49(2):207-218

39. Monteiro N, Martins A, Reis RL, Neves NM (2014) Liposomes in tissue engineering and regenerative medicine. J R Soc Interface 11(101):20140459

40. Knudsen KB, Northeved H, Kumar PE, Permin A, Gjetting T, Andresen TL, Larsen S, Wegener KM, Lykkesfeldt J, Jantzen K, Loft S, Moller P, Roursgaard M (2015) In vivo toxicity of cationic micelles and liposomes. Nanomedicine 11(2):467-477 
41. Cui ZK, Fan J, Kim S, Bezouglaia O, Fartash A, Wu BM, Aghaloo T, Lee M (2015) Delivery of siRNA via cationic Sterosomes to enhance osteogenic differentiation of mesenchymal stem cells. J Control Release 217:42-52

42. Jeon SY, Park JS, Yang HN, Woo DG, Park KH (2012) Codelivery of SOX9 genes and anti-Cbfa-1 siRNA coated onto PLGA nanoparticles for chondrogenesis of human MSCs. Biomaterials 33(17):4413-4423

43. Yan H, Duan X, Pan H, Holguin N, Rai MF, Akk A, Springer LE, Wickline SA, Sandell LJ, Pham CT (2016) Suppression of NF-kappaB activity via nanoparticle-based siRNA delivery alters early cartilage responses to injury. Proc Natl Acad Sci USA 113(41):E6199-E6208

44. Rosenthal SJ, Chang JC, Kovtun O, McBride JR, Tomlinson ID (2011) Biocompatible quantum dots for biological applications. Chem Biol 18(1):10-24

45. Xu J, Li J, Lin S, Wu T, Huang H, Zhang K, Sun Y, Yeung KW, Li G, Bian L (2016) Nanocarrier-mediated codelivery of small molecular drugs and siRNA to enhance chondrogenic differentiation and suppress hypertrophy of human mesenchymal stem cells. Adv Funct Mater 26(15):2643-2672

46. Wu Y, Zhou B, Xu F, Wang X, Liu G, Zheng L, Zhao J, Zhang $X$ (2016) Functional quantum dot-siRNA nanoplexes to regulate chondrogenic differentiation of mesenchymal stem cells. Acta Biomater 46:165-176

47. Lamichhane TN, Raiker RS, Jay SM (2015) Exogenous DNA loading into extracellular vesicles via electroporation is sizedependent and enables limited gene delivery. Mol Pharm 12(10):3650-3657

48. Banizs AB, Huang T, Dryden K, Berr SS, Stone JR, Nakamoto RK, Shi W, He J (2014) In vitro evaluation of endothelial exosomes as carriers for small interfering ribonucleic acid delivery. Int J Nanomedicine 9:4223-4230

49. Kaneti L, Bronshtein T, Malkah Dayan N, Kovregina I, Letko Khait N, Lupu-Haber Y, Fliman M, Schoen BW, Kaneti G, Machluf M (2016) Nanoghosts as a novel natural nonviral gene delivery platform safely targeting multiple cancers. Nano Lett 16(3):1574-1582

50. Toledano Furman NE, Lupu-Haber Y, Bronshtein T, Kaneti L, Letko N, Weinstein E, Baruch L, Machluf M (2013) Reconstructed stem cell nanoghosts: a natural tumor targeting platform. Nano Lett 13(7):3248-3255

51. Green JD, Tollemar V, Dougherty M, Yan Z, Yin L, Ye J, Collier Z, Mohammed MK, Haydon RC, Luu HH, Kang R, Lee MJ, Ho SH, He TC, Shi LL, Athiviraham A (2015) Multifaceted signaling regulators of chondrogenesis: implications in cartilage regeneration and tissue engineering. Genes Dis 2(4):307-327

52. Takeda S, Bonnamy JP, Owen MJ, Ducy P, Karsenty G (2001) Continuous expression of Cbfa1 in nonhypertrophic chondrocytes uncovers its ability to induce hypertrophic chondrocyte differentiation and partially rescues Cbfa1-deficient mice. Genes Dev 15(4):467-481

53. Koelling S, Kruegel J, Irmer M, Path JR, Sadowski B, Miro X, Miosge N (2009) Migratory chondrogenic progenitor cells from repair tissue during the later stages of human osteoarthritis. Cell Stem Cell 4(4):324-335

54. Schminke B, Muhammad H, Bode C, Sadowski B, Gerter R, Gersdorff N, Burgers R, Monsonego-Ornan E, Rosen V, Miosge $\mathrm{N}$ (2014) A discoidin domain receptor 1 knock-out mouse as a novel model for osteoarthritis of the temporomandibular joint. Cell Mol Life Sci 71(6):1081-1096

55. Lorda-Diez CI, Montero JA, Martinez-Cue C, Garcia-Porrero JA, Hurle JM (2009) Transforming growth factors beta coordinate cartilage and tendon differentiation in the developing limb mesenchyme. J Biol Chem 284(43):29988-29996
56. Chen L, Jiang C, Tiwari SR, Shrestha A, Xu P, Liang W, Sun Y, He S, Cheng B (2015) TGIF1 gene silencing in tendon-derived stem cells improves the tendon-to-bone insertion site regeneration. Cell Physiol Biochem 37(6):2101-2114

57. Li J, Chen L, Sun L, Chen H, Sun Y, Jiang C, Cheng B (2015) Silencing of TGIF1 in bone mesenchymal stem cells applied to the post-operative rotator cuff improves both functional and histologic outcomes. J Mol Histol 46(3):241-249

58. Bobick BE, Cobb J (2012) Shox2 regulates progression through chondrogenesis in the mouse proximal limb. J Cell Sci $125(\mathrm{Pt}$ 24):6071-6083

59. Tian Y, Xu Y, Fu Q, Chang M, Wang Y, Shang X, Wan C, Marymont JV, Dong Y (2015) Notch inhibits chondrogenic differentiation of mesenchymal progenitor cells by targeting Twist1. Mol Cell Endocrinol 403:30-38

60. Lolli A, Lambertini E, Penolazzi L, Angelozzi M, Morganti C, Franceschetti T, Pelucchi S, Gambari R, Piva R (2014) Prochondrogenic effect of miR-221 and slug depletion in human MSCs. Stem Cell Rev 10(6):841-855

61. Lisignoli G, Manferdini C, Lambertini E, Zini N, Angelozzi M, Gabusi E, Gambari L, Penolazzi L, Lolli A, Facchini A, Piva R (2014) Chondrogenic potential of Slug-depleted human mesenchymal stem cells. Tissue Eng Part A 20(19-20):2795-2805

62. Beier F (2005) Cell-cycle control and the cartilage growth plate. J Cell Physiol 202(1):1-8

63. Zhong W, Li Y, Li L, Zhang W, Wang S, Zheng X (2013) YAPmediated regulation of the chondrogenic phenotype in response to matrix elasticity. J Mol Histol 44(5):587-595

64. Zhou HW, Lou SQ, Zhang K (2004) Recovery of function in osteoarthritic chondrocytes induced by p16INK4a-specific siRNA in vitro. Rheumatology (Oxford) 43(5):555-568

65. Ijiri K, Zerbini LF, Peng H, Correa RG, Lu B, Walsh N, Zhao Y, Taniguchi N, Huang XL, Otu H, Wang H, Wang JF, Komiya S, Ducy P, Rahman MU, Flavell RA, Gravallese EM, Oettgen P, Libermann TA, Goldring MB (2005) A novel role for GADD45beta as a mediator of MMP-13 gene expression during chondrocyte terminal differentiation. J Biol Chem 280(46):38544-38555

66. Bobick BE, Matsche AI, Chen FH, Tuan RS (2010) The ERK5 and ERK1/2 signaling pathways play opposing regulatory roles during chondrogenesis of adult human bone marrow-derived multipotent progenitor cells. J Cell Physiol 224(1):178-186

67. Olivotto E, Borzi RM, Vitellozzi R, Pagani S, Facchini A, Battistelli M, Penzo M, Li X, Flamigni F, Li J, Falcieri E, Facchini A, Marcu KB (2008) Differential requirements for IKKalpha and IKKbeta in the differentiation of primary human osteoarthritic chondrocytes. Arthritis Rheum 58(1):227-239

68. Kawakita K, Nishiyama T, Fujishiro T, Hayashi S, Kanzaki N, Hashimoto S, Takebe K, Iwasa K, Sakata S, Nishida K, Kuroda R, Kurosaka M (2012) Akt phosphorylation in human chondrocytes is regulated by p53R 2 in response to mechanical stress. Osteoarthritis Cartilage 20(12):1603-1609

69. Thoms BL, Murphy CL (2010) Inhibition of hypoxia-inducible factor-targeting prolyl hydroxylase domain-containing protein 2 (PHD2) enhances matrix synthesis by human chondrocytes. J Biol Chem 285(27):20472-20480

70. Dong R, Yao R, Du J, Wang S, Fan Z (2013) Depletion of histone demethylase KDM2A enhanced the adipogenic and chondrogenic differentiation potentials of stem cells from apical papilla. Exp Cell Res 319(18):2874-2882

71. McDermott BT, Ellis S, Bou-Gharios G, Clegg PD, Tew SR (2016) RNA binding proteins regulate anabolic and catabolic gene expression in chondrocytes. Osteoarthritis Cartilage 24(7):1263-1273

72. Zeng G, Cui X, Liu Z, Zhao H, Zheng X, Zhang B, Xia C (2014) Disruption of phosphoinositide-specific phospholipases 
Cgamma1 contributes to extracellular matrix synthesis of human osteoarthritis chondrocytes. Int J Mol Sci 15(8):13236-13246

73. Karlsen TA, Jakobsen RB, Mikkelsen TS, Brinchmann JE (2014) microRNA-140 targets RALA and regulates chondrogenic differentiation of human mesenchymal stem cells by translational enhancement of SOX9 and ACAN. Stem Cells Dev 23(3):290-304

74. Song L, Webb NE, Song Y, Tuan RS (2006) Identification and functional analysis of candidate genes regulating mesenchymal stem cell self-renewal and multipotency. Stem Cells 24(7):1707-1718

75. Hattori T, Kishino T, Stephen S, Eberspaecher H, Maki S, Takigawa M, de Crombrugghe B, Yasuda H (2013) E6-AP/ UBE3A protein acts as a ubiquitin ligase toward SOX9 protein. J Biol Chem 288(49):35138-35148

76. Chen E, Tang MK, Yao Y, Yau WW, Lo LM, Yang X, Chui YL, Chan J, Lee KK (2013) Silencing BRE expression in human umbilical cord perivascular (HUCPV) progenitor cells accelerates osteogenic and chondrogenic differentiation. PLoS One 8(7):e67896

77. Zhang F, Yao Y, Su K, Fang Y, Citra F, Wang DA (2015) Cotransduction of lentiviral and adenoviral vectors for co-delivery of growth factor and shRNA genes in mesenchymal stem cellsbased chondrogenic system. J Tissue Eng Regen Med 9(9):1036-1045

78. Twomey JD, Thakore PI, Hartman DA, Myers EG, Hsieh AH (2014) Roles of type VI collagen and decorin in human mesenchymal stem cell biophysics during chondrogenic differentiation. Eur Cell Mater 27:237-250

79. Kafienah W, Cheung FL, Sims T, Martin I, Miot S, Von Ruhland C, Roughley PJ, Hollander AP (2008) Lumican inhibits collagen deposition in tissue engineered cartilage. Matrix Biol 27(6):526-534

80. Nakajima M, Kizawa H, Saitoh M, Kou I, Miyazono K, Ikegawa S (2007) Mechanisms for asporin function and regulation in articular cartilage. J Biol Chem 282(44):32185-32192

81. Wang ZH, Yang ZQ, He XJ, Kamal BE, Xing Z (2010) Lentivirus-mediated knockdown of aggrecanase- 1 and -2 promotes chondrocyte-engineered cartilage formation in vitro. Biotechnol Bioeng 107(4):730-736

82. Jin EJ, Choi YA, Kyun Park E, Bang OS, Kang SS (2007) MMP-2 functions as a negative regulator of chondrogenic cell condensation via down-regulation of the FAK-integrin beta1 interaction. Dev Biol 308(2):474-484

83. Zhang X, Crawford R, Xiao Y (2016) Inhibition of vascular endothelial growth factor with shRNA in chondrocytes ameliorates osteoarthritis. J Mol Med (Berl) 94(7):787-798

84. Wei F, Zhou J, Wei X, Zhang J, Fleming BC, Terek R, Pei M, Chen Q, Liu T, Wei L (2012) Activation of Indian hedgehog promotes chondrocyte hypertrophy and upregulation of MMP13 in human osteoarthritic cartilage. Osteoarthritis Cartilage 20(7):755-763

85. Morigele M, Shao Z, Zhang Z, Kaige M, Zhang Y, Qiang W, Yang S (2013) TGF-betal induces a nucleus pulposus-like phenotype in Notch 1 knockdown rabbit bone marrow mesenchymal stem cells. Cell Biol Int 37(8):820-825

86. Ryu JH, Chun JS (2006) Opposing roles of WNT-5A and WNT11 in interleukin-1beta regulation of type II collagen expression in articular chondrocytes. J Biol Chem 281(31):22039-22047

87. Takahashi T, Ogasawara T, Asawa Y, Mori Y, Uchinuma E, Takato T, Hoshi K (2007) Three-dimensional microenvironments retain chondrocyte phenotypes during proliferation culture. Tissue Eng 13(7):1583-1592

88. Hasegawa A, Yonezawa T, Taniguchi N, Otabe K, Akasaki Y, Matsukawa T, Saito M, Neo M, Marmorstein LY, Lotz MK (2016) Fibulin-3 in joint aging and osteoarthritis pathogenesis. Arthritis Rheumatol 69(3):576-585
89. Jones SW, Brockbank SM, Mobbs ML, Le Good NJ, SomaHaddrick S, Heuze AJ, Langham CJ, Timms D, Newham P, Needham MR (2006) The orphan G-protein coupled receptor RDC1: evidence for a role in chondrocyte hypertrophy and articular cartilage matrix turnover. Osteoarthritis Cartilage 14(6):597-608

90. Le LT, Swingler TE, Clark IM (2013) Review: the role of microRNAs in osteoarthritis and chondrogenesis. Arthritis Rheum 65(8):1963-1974

91. Martinez-Sanchez A, Dudek KA, Murphy CL (2012) Regulation of human chondrocyte function through direct inhibition of cartilage master regulator SOX9 by microRNA-145 (miRNA145). J Biol Chem 287(2):916-924

92. Diederichs S, Gabler J, Autenrieth J, Kynast KL, Merle C, Walles H, Utikal J, Richter W (2016) Differential regulation of SOX9 protein during chondrogenesis of induced pluripotent stem cells versus mesenchymal stromal cells: a shortcoming for cartilage formation. Stem Cells Dev 25(8):598-609

93. Ukai T, Sato M, Akutsu H, Umezawa A, Mochida J (2012) MicroRNA-199a-3p, microRNA-193b, and microRNA-320c are correlated to aging and regulate human cartilage metabolism. J Orthop Res 30(12):1915-1922

94. Lee S, Yoon DS, Paik S, Lee KM, Jang Y, Lee JW (2014) microRNA-495 inhibits chondrogenic differentiation in human mesenchymal stem cells by targeting Sox9. Stem Cells Dev 23(15): 1798-1808

95. Martinez-Sanchez A, Murphy CL (2013) miR-1247 functions by targeting cartilage transcription factor SOX9. J Biol Chem 288(43):30802-30814

96. Xu J, Kang Y, Liao WM, Yu L (2012) MiR-194 regulates chondrogenic differentiation of human adipose-derived stem cells by targeting Sox5. PLoS ONE 7(3):e31861

97. Song J, Kim D, Chun CH, Jin EJ (2013) MicroRNA-375, a new regulator of cadherin-7, suppresses the migration of chondrogenic progenitors. Cell Signal 25(3):698-706

98. Kim D, Song J, Kim S, Park HM, Chun CH, Sonn J, Jin EJ (2012) MicroRNA-34a modulates cytoskeletal dynamics through regulating RhoA/Rac1 cross-talk in chondroblasts. J Biol Chem 287(15):12501-12509

99. Kim D, Song J, Kim S, Kang SS, Jin EJ (2011) MicroRNA-142$3 p$ regulates TGF-beta3-mediated region-dependent chondrogenesis by regulating ADAM9. Biochem Biophys Res Commun 414(4):653-659

100. Kim D, Song J, Kim S, Chun CH, Jin EJ (2011) MicroRNA-34a regulates migration of chondroblast and IL-1beta-induced degeneration of chondrocytes by targeting EphA5. Biochem Biophys Res Commun 415(4):551-557

101. Zhou X, Wang J, Sun H, Qi Y, Xu W, Luo D, Jin X, Li C, Chen W, Lin Z, Li F, Zhang R, Li G (2016) MicroRNA-99a regulates early chondrogenic differentiation of rat mesenchymal stem cells by targeting the BMPR2 gene. Cell Tissue Res 366(1):143-153

102. Yoshizuka M, Nakasa T, Kawanishi Y, Hachisuka S, Furuta T, Miyaki S, Adachi N, Ochi M (2016) Inhibition of microRNA222 expression accelerates bone healing with enhancement of osteogenesis, chondrogenesis, and angiogenesis in a rat refractory fracture model. J Orthop Sci 21(6):852-858

103. Guerit D, Brondello JM, Chuchana P, Philipot D, Toupet K, Bony C, Jorgensen C, Noel D (2014) FOXO3A regulation by miRNA-29a Controls chondrogenic differentiation of mesenchymal stem cells and cartilage formation. Stem Cells Dev 23(11):1195-1205

104. Seidl CI, Martinez-Sanchez A, Murphy CL (2016) Derepression of MicroRNA-138 contributes to loss of the human articular chondrocyte phenotype. Arthritis Rheumatol 68(2):398-409

105. Song J, Lee M, Kim D, Han J, Chun CH, Jin EJ (2013) MicroRNA-181b regulates articular chondrocytes differentiation 
and cartilage integrity. Biochem Biophys Res Commun 431(2):210-214

106. Paik S, Jung HS, Lee S, Yoon DS, Park MS, Lee JW (2012) miR-449a regulates the chondrogenesis of human mesenchymal stem cells through direct targeting of lymphoid enhancer-binding factor-1. Stem Cells Dev 21(18):3298-3308

107. Chen WK, Yu XH, Yang W, Wang C, He WS, Yan YG, Zhang J, Wang WJ (2017) lncRNAs: novel players in intervertebral disc degeneration and osteoarthritis. Cell Prolif 50(1):e12313

108. Liu Q, Zhang X, Hu X, Dai L, Fu X, Zhang J, Ao Y (2016) Circular RNA related to the chondrocyte ECM regulates MMP13 expression by functioning as a MiR-136 'Sponge' in human cartilage degradation. Sci Rep 6:22572

109. Liu Q, Zhang X, Dai L, Hu X, Zhu J, Li L, Zhou C, Ao Y (2014) Long noncoding RNA related to cartilage injury promotes chondrocyte extracellular matrix degradation in osteoarthritis. Arthritis Rheumatol 66(4):969-978

110. Li J, Dong S (2016) The signaling pathways involved in chondrocyte differentiation and hypertrophic differentiation. Stem Cells Int 2016:2470351

111. de Vries-van Melle ML, Narcisi R, Kops N, Koevoet WJ, Bos PK, Murphy JM, Verhaar JA, van der Kraan PM, van Osch GJ (2014) Chondrogenesis of mesenchymal stem cells in an osteochondral environment is mediated by the subchondral bone. Tissue Eng Part A 20(1-2):23-33

112. Fahy N, de Vries-van Melle ML, Lehmann J, Wei W, Grotenhuis N, Farrell E, van der Kraan PM, Murphy JM, BastiaansenJenniskens YM, van Osch GJ (2014) Human osteoarthritic synovium impacts chondrogenic differentiation of mesenchymal stem cells via macrophage polarisation state. Osteoarthritis Cartilage 22(8):1167-1175

113. Wei W, Rudjito E, Fahy N, Verhaar JA, Clockaerts S, Bastiaansen-Jenniskens YM, van Osch GJ (2015) The infrapatellar fat pad from diseased joints inhibits chondrogenesis of mesenchymal stem cells. Eur Cell Mater 30:303-314

114. Lane SW, Williams DA, Watt FM (2014) Modulating the stem cell niche for tissue regeneration. Nat Biotechnol 32(8):795-803

115. Shapiro F, Koide S, Glimcher MJ (1993) Cell origin and differentiation in the repair of full-thickness defects of articular cartilage. J Bone Joint Surg Am 75(4):532-553

116. Hunziker EB, Rosenberg LC (1996) Repair of partial-thickness defects in articular cartilage: cell recruitment from the synovial membrane. J Bone Joint Surg Am 78(5):721-733
117. Chan CM, Macdonald CD, Litherland GJ, Wilkinson DJ, Skelton A, Europe-Finner GN, Rowan AD (2017) Cytokine-induced MMP13 expression in human chondrocytes is dependent on activating transcription factor 3 (ATF3) regulation. J Biol Chem 292(5):1625-1636

118. Lu X, Lin J, Jin J, Qian W, Weng X (2016) Hsa-miR-15a exerts protective effects against osteoarthritis by targeting aggrecanase-2 (ADAMTS5) in human chondrocytes. Int J Mol Med 37(2):509-516

119. Akagi R, Akatsu Y, Fisch KM, Alvarez-Garcia O, Teramura T, Muramatsu Y, Saito M, Sasho T, Su AI, Lotz MK (2016) Dysregulated circadian rhythm pathway in human osteoarthritis: NR1D1 and BMAL1 suppression alters TGF-beta signaling in chondrocytes. Osteoarthr Cartil. doi:10.1016/j.joca.2016.11.007

120. Preitschopf A, Schorghofer D, Kinslechner K, Schutz B, Zwickl H, Rosner M, Joo JG, Nehrer S, Hengstschlager M, Mikula M (2016) Rapamycin-Induced Hypoxia Inducible Factor 2A Is Essential for Chondrogenic Differentiation of Amniotic Fluid Stem Cells. Stem Cells Transl Med 5(5):580-590

121. Andre EM, Pensado A, Resnier P, Braz L, Rosa da Costa AM, Passirani C, Sanchez A, Montero-Menei CN (2016) Characterization and comparison of two novel nanosystems associated with siRNA for cellular therapy. Int J Pharm 497(1-2):255-267

122. Zhao J, Fan X, Zhang Q, Sun F, Li X, Xiong C, Zhang C, Fan H (2014) Chitosan-plasmid DNA nanoparticles encoding small hairpin RNA targeting MMP-3 and -13 to inhibit the expression of dedifferentiation related genes in expanded chondrocytes. J Biomed Mater Res A 102(2):373-380

123. Schade A, Delyagina E, Scharfenberg D, Skorska A, Lux C, David R, Steinhoff G (2013) Innovative strategy for microRNA delivery in human mesenchymal stem cells via magnetic nanoparticles. Int J Mol Sci 14(6):10710-10726

124. Peng X, Yang L, Chang H, Dai G, Wang F, Duan X, Guo L, Zhang Y, Chen G (2014) Wnt/beta-catenin signaling regulates the proliferation and differentiation of mesenchymal progenitor cells through the p53 pathway. PLoS ONE 9(5):e97283

125. Laine SK, Alm JJ, Virtanen SP, Aro HT, Laitala-Leinonen TK (2012) MicroRNAs miR-96, miR-124, and miR-199a regulate gene expression in human bone marrow-derived mesenchymal stem cells. J Cell Biochem 113(8):2687-2695 